\title{
Research on Construction of Fuzhou International Shipping Center under the Perspective of Free Trade Zone
}

\author{
Lihua Huang \\ Fuzhou University of International Studies and Trade \\ Fuzhou, China 350200
}

\author{
Jie Zhu \\ Fuzhou University of International Studies and Trade \\ Fuzhou, China 350200
}

\begin{abstract}
The construction of Fujian Free Trade Zone has higher requirements for Fuzhou regional international shipping center. From the perspective of free trade zone, this paper refers to the experience of advantages and disadvantages in the construction of Shanghai international shipping center and proposes suggestions to accelerate the construction of Fuzhou international shipping center.
\end{abstract}

Keywords-free trade zone; Fuzhou; international shipping center

\section{INFLUENCE OF FREE TRADE ZONE ON INTERNATIONAL} SHIPPING

\section{A. Background of Founding Free Trade Zone}

In 2008, the economic crisis broke out worldwide, leading to earth-shaking changes of economic and trade environment. Major developed countries and regions like Europe, America and Japan are deeply caught in it with weak economic growth. The excessive protectionist policy of Europe and America increases local economic and trade frictions. The WTO negotiation has no good news. The world trade protectionism emerges and drives the soaring development of regional free trade agreement. The economic status of developing countries in Asia improves increasingly and they accelerate development. The strength of economic entity in Asia is ever-increasing and close to EU and will exceed EU soon. Under the new situation of world economy, developed countries like EU and America actively build and promote TPP and TTIP, in order to integrate the economic and trade and investment structure of both sides, coordinate the policies of both sides, reduce economic and trade cost, promote economic growth and maintain the dominant position of international economic and trade pattern. Countries like China that are not highly open fail to get access to the highly free market of TPP and TTIP. As the world's second largest economic entity and the first trading power, China should show open trade.

The countermeasures of China for TPP and TTIP of America include: Firstly, actively promote the construction of RCEP. It does not include America but covers other members of TPP; secondly, actively promote the construction of free

Fund project: Research center of the theoretical system of socialism with Chinese characteristics of Fuzhou city, 2015 annual general project (Project No.: 2015B011). trade zone on mainland China. Under the new pattern of international economic and trade development, our country deepens reform, increases the degree of opening and builds the free trade zone, actively opening to the outside world. The key tasks include change the government functions, explore new management pattern, and enlarge the opening degree of service industry, communications industry and transport service and the open innovation of financial industry. In August 2013, the first free trade zone of China, Shanghai Free Trade Zone was founded formally. After one year, it injects new vitality to Chinese market and makes great achievements. In December 2014, the NPC approved the application of Guangdong Province, Tianjin City and Fujian Province in applying for the founding of free trade zones. They become the second batch of free trade zones after Shanghai. Fujian provincial Party committee applies for free trade zones in Mawei of Fuzhou, Haicang of Xiamen and Pingtan comprehensive trial plot in the form of "one region and three districts". The total area reaches $118.04 \mathrm{~km} 2$. In the end of March 2015, the overall plan of Fujian Free Trade Zone passed the deliberation. Fuzhou Free Trade Zone is founded formally.

\section{B. Influence of Fujian Free Trade Zone on International Shipping Construction}

Although the construction of Fujian Free Trade Zone can not influence the development of economy in many countries like generalized free trade zone, it more or less influences the international shipping development of Fujian. The influence of Fujian Free Trade Zone on international shipping mainly includes: the founding of Fujian Free Trade Zone will promote the construction of infrastructure of Fujian international shipping center and realize the efficient operation of port; the tax policy carried out in Fujian Free Trade Zone helps to improve the trade volume between regions; the free and open financial policy implemented in Fujian Free Trade Zone helps to improve the financial market of shipping and promote the development of industries related to shipping; Fujian Free Trade Zone lowers the demand to attract foreign shipping enterprises to enter, with the help of or learn advanced foreign technology and management experience to improve the regional shipping service quality and accelerate the development of international shipping. 


\section{THE CONSTRUCTION EXPERIENCE OF SHANGHAI INTERNATIONAL SHIPPING CENTER FOR FUZHOU INTERNATIONAL SHIPPING CENTER TO REFER}

In order to accelerate the construction of regional international shipping center and support the development of pilot free trade zone of Fuzhou, Fuzhou area of Fujian Free Trade Zone can refer to the construction experience of Shanghai international shipping center.

\section{A. The Advantage Experience of Shanghai International Shipping Center for Reference byFuzhou International Shipping Center}

1) Advantage experience of position in construction of Shanghai international shipping center: Located in the plain area of the middle and lower reaches of Yangtze River, Shanghai is a key hub connecting Yangtze River transport corridor with marine transport corridor with convenient transportation. It can reach inland areas through Yangtze River and transportation routes like Shanghai-Chongqing highway and Beijing-Shanghai railway. Waterways, highways and railways cover densely in Shanghai and surrounding area. Compared with three international shipping centers in London, Singapore and Rotterdam, Shanghai is not a halfpenny the worse in regional conditions. At present, many international maritime transport and auxiliary enterprises with different capital types carry out business activities in Shanghai. [1]

2) Advantage experience of policy in construction of Shanghai international shipping center: The founding of international shipping center should consider the superior regional condition and the construction of hard environment and soft environment. The construction of shipping center needs substantial support of the government. At present, the government has greatly supported the construction of shipping center and has made benign policy for the construction of Shanghai shipping center and Fujian shipping center. In September 2013, China (Shanghai) Pilot Free Trade Zone was founded formally. Shanghai Free Trade Zone seizes good change in financial innovation and trade liberalization. It expands the transfer function of port and attracts more shipping enterprises to gather to Shanghai Free Trade Zone, in order to promote the development of Shanghai shipping industrial clusters and improve international competitiveness.

\section{B. The Disadvantage Experience of Shanghai International Shipping Center for Reference byFuzhou International Shipping Center}

1) The collecting and distributing system of Shanghai international shipping center is unsound: The rapid development of transportation in Shanghai promotes the collecting and distributing of cargo in the Port of Shanghai. The capacity of highways, waterways, railways and air transport improves greatly and forms collecting and distributing system. However, the collecting and distributing system in Port of Shanghai still needs improvement. The main reasons include: the actual transfer efficiency is low and the cost of sea-railway combined transportation is high.

2) It lacks high-end talents of shipping service industry in the construction of Shanghai international shipping center:
There are many people engaging in shipping but most of them have low educational background and can only work on basic shipping services. It lacks talents of high-end shipping service industry. At present, the employees in high-end shipping industry of Shanghai only account for $1 \%$ of the total number of employees in the shipping service industry of Shanghai. In comparison, the employees in high-end shipping industry of London account for $85 \%$ of the total number of employees in the shipping industry[2]. The shortage of high-end shipping talents makes Shanghai fail to sufficiently and effectively use resources of shipping service in the development of high-end shipping service industry, restricting the development of service industry.

3) The financial market policy in the construction of Shanghai international shipping center lacks innovation: China (Shanghai) Pilot Free Trade Zone has founded formally but it is at the initial stage with foreign exchange control. The great development of financial market needs free and benign environment, but the strict financial supervision system in our country restricts the innovation of financial market. The offshore financial business of Shanghai fails to carry out successfully, so that the financial institutions of shipping are restricted to fund the shipping enterprises.

4) The legal service of shipping fails to keep pace with the global level in the construction of Shanghai international shipping center: Our country only has several laws and regulations in shipping like Maritime Traffic Safety Law, Maritime Law, Port Law and Ship Law, which are at the initial stage. Furthermore, the contents of some laws are backward, failing to solve realistic problems in shipping market. In the provision of legal service, because the immature laws and regulations cannot keep pace with the international level, Shanghai international shipping center provides few legal services and has inadequate international influence.

Besides, the introduction of preferential tariff policies and preferential policies in simplifying customs clearance procedures in Shanghai Free Trade Zone will attract more ships and cargos to export in Port of Shanghai and further improve the business volume of cargo. On the other hand, the policy of "Coastal Shipping Pilot Zone" will attract cargos running off to nearby competitive ports to transfer in Shanghai. It is of great advantage to the improvement of international transfer amount in Shanghai.

\section{SUGGESTIONS TO ACCELERATE THE CONSTRUCTION OF FUZHOU INTERNATIONAL SHIPPING CENTER}

\section{A. Optimize the Collecting and Distributing System of Fuzhou International Shipping Center}

The collecting and distributing system of Shanghai international shipping center is unsound. We should pursue reasonable and efficient structure in the construction of regional international shipping center in Fuzhou. In the construction of regional shipping center, Fuzhou should learn lessons of Shanghai in collecting and distributing system that the transfer proportion of highways is too high and the transfer proportion of waterways is low and the transfer proportion of 
railways is low continuously, and optimize the collecting and distributing system of Fuzhou international shipping center.

The collecting and distributing proportion of highways should be confined to a reasonable scope. The optimization should focus on management and coordination, pay attention to the management of port logistics parks, deepening the flexible toll policy and diverging traffic volume.

Because the waterway transport has large freight volume and low cost, the collecting and distributing of waterway is the key to improve the collecting and distributing system of Port of Shanghai. We can accelerate the construction of inland waterway and the application of large ships. The application of large ships helps to improve the freight volume of containers and effectively reduce the loss of time and cost caused by loading and unloading of cargos. It is an important link to strengthen the construction of waterway collecting and distributing.

The collecting and distributing of railways should connect railways and ports. So far, many ports fail to construct railways. Therefore, we can cooperate with railway interests and realize the mutual application of self-owned containers of ship-owing companies and railway containers.[3]

\section{B. Intensify the Introduction of High-Level Talents in Fuzhou International Shipping Center}

High-level talents play a vital role in the construction of international shipping center. It is necessary to train high-level talents and increase fund input for Fuzhou international shipping center, in order to improve the quality and professional skills of talents. The government can make corresponding preferential policies like rewards and tax preference to bring talents in Fuzhou. However, it is inadequate to introduce talents. The key is how to retain talents. They can provide preferential household registration system and preferential policies in purchasing house, in order to provide intelligence security for the construction of Fuzhou international shipping center.

\section{Accelerate the Innovation of Shipping Financial System in Fuzhou International Shipping Center}

In August 2013, China (Shanghai) Pilot Free Trade Zone was founded formally to carry out pilot project construction in Shanghai Waigaoqiao Free Trade Zone, Waigaoqiao Bonded Logistics Park, Yangshan Bonded Port Zone and Comprehensive Bonded Zone in Pudong Airport. At present, the construction of China (Shanghai) Pilot Free Trade Zone is following the prescribed order. The moderate deregulation of government gradually realizes. The founding of free trade zone can bring some financial preferential policies for Fuzhou like interest rate liberalization and foreign exchange management system. These policies influence the development of financial system in Fuzhou international shipping center. In regard to the shipping financial system of Fuzhou international shipping center, the government can regulate the market and relax restrictions of financial policies of shipping moderately, in order to strengthen the financial cluster capacity and promote the development of shipping finance of Fuzhou international shipping center.

\section{Improve the Law And Regulation System of Shipping Industry of Fuzhou International Shipping Center}

There are few shipping laws in our country. Some of them are outdated, failing to keep pace with the shipping development and meet the requirement of new situation in shipping. After the founding of Fuzhou Free Trade Zone, a series of policies and regulations are launched and make up for the deficiencies that the legislation of shipping industry are backward, the relevant laws and regulations are imperfect and fail to keep up with the international level. But Fuzhou Free Trade Zone only involves the local area. Therefore, Fuzhou international shipping center can draw lessons from the successful experience of Shanghai international shipping center and make more comprehensive legal system with Fuzhou characteristics and broader radiation scope and improve the legal environment of shipping service.

\section{CONCLUSION}

The construction of free trade zone in our country provides a new perspective for international shipping. Shanghai international shipping has experience in policy advantage and position advantage but also has disadvantages like the legal service of shipping fails to keep pace with the international level, the policies in financial market are deficient in innovation, high-end talents of shipping service are insufficient and the collecting and distributing system is unsound. We can promote the development of Fuzhou international shipping center through optimizing the collecting and distributing system of it, bringing in high-level talents, accelerating the innovation of shipping financial system and improving law and regulation system of shipping industry.

\section{REFERENCES}

[1] Shanghai Municipal People's Government, the "12th Five-year" Plan to Accelerate the Construction of Shanghai International Shipping Center [J], Containerization, 2012(11): 27-31

[2] Wang Chuanxu, Dong Gang. International Experience of Coordinated Development of Shipping Center and City and Shanghai Strategy [J], Scientific Development, 2012(10): 48-54

[3] $\mathrm{Yu}$ Chen. Urgent for Shanghai to Optimize Modern Urban Collecting and Distributing System-Summary of Seminar on Construction of Shanghai Urban Collecting and Distributing System under the Perspective of International Shipping Center [J], Shanghai Urban Management, 2013(4): 84-85 